\title{
EVALUATION OF WORK CONDITIONS AND OCCUPATIONAL HEALTH RISK FACTORS IN ENTERPRISES WITHIN A 10-YEAR PERIOD IN LATVIA
}

\author{
Dagmāra Sprūdža*, Maija Eglìte*, Mārìte Ārija Baḳe*, Žanna Martinsone*, \\ Linda Matisāne $e^{\star *}$, Inese Mārtiņsone*, Anita Piḳe*, and Ivars Vanadziṇš ${ }^{*}$ \\ * Institute of Occupational Safety and Environmental Health, Rĩga Stradiṇš University, LATVIA \\ E-mail: dagmara.sprudza@ rsu.lv \\ ** S/C Inspecta Latvia, Slokas iela 13, Rīga, LV-1048, LATVIA
}

Communicated by Vija Kluša

\begin{abstract}
The objective of the study was to conduct a survey in the field of occupational health and safety the results of which could be used in rational and effective decision making for elaboration of employment and social policy programmes and for ensuring occupational safety and health programme development. During the study the following groups of people were surveyed: employers, occupational health and safety specialists, and employees. The traditional work risk factors (physical, chemical, biological) have changed to new risks (psychosocial, ergonomic, microclimatic) in Latvia today. The study included objective assessment of occupational health and safety situation (analysis of work environment risk factors measurement data bases, information on occupational diseases, workplace accidents). Results of measurements showed that one-third of measured risk factors values exceeded mandatory or recommended limits but situation has been improved during the last years (2002 compared to 2006). The results of surveys reveal insufficient assessment of risk factors in workplaces and selection of most hazardous ones only. Awareness and understanding of employers and employees regarding occupational health and safety requirements was dissatisfactory. The results of the study reveal a low level of workplace accidents compared to other countries within EU, which may be the result of poor registration system in Latvia. Strengthening of occupational safety and health normative basis and improvement of qualification of occupational physicians has increased the number of occupational diseases and patients revealed for the first time from 1996 to 2006. Early diagnose of occupational diseases and effective rehabilitation is an important question to favour a more rapid return of workforce after occupational morbidity. Study showed that attention should further be paid to simplification of legal requirements, development of alternative methods for informing and educating people, as well as recurrent definition of national indicators to assess efficacy of implemented measures related to occupational health and safety.
\end{abstract}

Key words: occupational health and safety, legislation, work risk factors, awareness.

\section{INTRODUCTION}

Work shapes our life, ensures our independency, affects mental and physical health and facilitates social welfare. The work environment has a significant impact on biological processess of a human body, and thus, can directly affect safety, health and work ablitity of an employee (Riedman et al., 2006).

Our rapidly changing living environment is closely related to changes in the work environment: work is becoming more intense and requires maximum attention and concentration, adaptation of work with mental and physical capacity of an individual, as well as dealing with different managerial issues (Kauppinen et al., 2006). Traditional work environment risks still exist, such as noise, vibration, dust, chemical substances etc. Approximately 100000 chemical substances, 50 physical factors, 200 biological factors, 20 ergonomic factors and similar numbers of factors related to physical loads are considered as occupational hazards (Anonymous, 1995; Rantanen et al., 2002; Anonymous, 2003). Occupational risk factors occur in all economic sectors and can affect large numbers of employees (Jankauskas, 2000; Eglite, 2000; Viikari-Juntura et al., 2001; Ijzelenberg et al., 2004).

It is impossible to maintain a working environment without any risk factors. Therefore, reduction and control of risks is a responsibility of every employer. Policy documents at all levels, including international and EU levels, as well as na- 
tional planning and development documents have all shaped occupational health and safety as a specific focus area in Latvia. The occupational health and safety legislation system has been upgraded successfully, thereby ensuring a shift from the old system to the new one, which has its roots in the requirements of the European Union. Occupational health and safety in Latvia is regulated by several laws. The most relevant are the Labour Law, 2001, and Labour Protection Law, 2001, as well as more than 30 resolutions of the Cabinet of Ministers and linked standards (LVS EN; LVS ISO). In spite of many informative explanatory publications (guidelines, brochures, booklets) that have been issued in Latvia during the last 5-6 years, awareness of general public regarding provisions of the regulations on occupational risk assessments and other related issues is dissatisfactory. According to the Labour Protection Law, preventive measures mean activities or measures that are planned or implemented in all work stages to prevent and reduce occupational risks. The objective of these measures is to establish a safe and healthy work environment and to prevent workplace accidents and occupational diseases. A new policy document, „Occupational health and safety development principles 2007-013", has been completed, and elaboration of the new "Occupational health and safety development programme 2007-2010" has been initiated now.

In the period 1996-2007 in Latvia, nine research and studies funded from Latvian Council of Science and in collaboration with other European countries have been carried out (Eglite et al., 2002,). Such studies are most often carried out by Latvian institutes and higher educational establishments; they are in the form of applied research, and therefore, directly reflect conditions of the working environment in Latvia (for example, studies in wood processing, logging, metalworking and textile industry). In Latvia relatively few studies have been carried out to survey the occupational health and safety situation in Latvia, with the aim to aid decision making (Eglite et al., 2002, Фарбтух и др., 2002; Roja et al., 2006).

There seems to be a need to consider the existing situation, as well as historic, economic and social features, in comparison to other countries, despite the unified European Union requirements. It should be also noted that in Latvia no single national strategy in occupational health and safety has been approved, which includes priorities, objectives to be reached in the future, justified solutions to existing problems and required changes in the field of occupational health and safety.

The aim of the present study was to conduct a survey in the field of occupational health and safety, which would be used to improve rational and effective decision-making for elaboration of employment and social policy programmes and for ensuring sustainable development.

\section{MATERIALS AND METHODS}

The following surveys and analyses were carried out during the study:
1) Survey of employers, employees, general public, occupational health and safety specialists, as well as specially protected and socially castaway groups of individuals; analysis and summary of the obtained results. Six surveys were carried out in the frame of the study "Work conditions and risks in Latvia":

- survey of employers and their representatives $(n=1058)$;

- survey of employees $(n=2520)$, including self-employed persons $(n=65)$;

- survey of permanent residents of Latvia $(n=1015)$;

- survey of specialists having or still continuing higher professional education in the field of occupational health and safety $(\mathrm{n}=86)$;

- survey of representatives of specially protected and socially castaway groups $(n=406)$.

2) Analysis of databases ( $n=6871$ enterprises and companies). The database of measurements was established in the period 01.01 .1995 - 31.12.2005 by the Laboratory of Hygiene and Occupational Diseases. The database comprises measurements out in 13956 workplaces: chemical substances in 4525 workplaces; noise level in 4420 workplaces; whole-body vibration in 310 workplaces; microclimate, including ventilation assessment in in 6706 workplaces; and lighting in 2354 workplaces.

3) Analysis of registered occupational diseases and work accidents according to the State Labour Inspection and Centre of Occupational and Radiation Medicine of Pauls Stradiņš Clinical Hospital data basis

SPSS (version 14 statistical package for Windows) and Microsoft Excel were used for statistical analyses.

\section{RESULTS}

\section{Analysis of the survey}

Satisfaction with job and work conditions. The results demonstrate that employees in Latvia have generally higher job satisfaction than self-employed persons (Fig. 1). It was found that $75.0 \%$ of employees and $56.1 \%$ of the selfemployed were more or less satisfied with their current jobs. Among employees, higher rates of dissatisfaction were in the manufacturing industry $(37.1 \%)$, manufacture of basic metals, fabricated metal products, machinery and equipment $(33.7 \%)$, and manufacture of wood and cork products and furniture (30.2\%). It is not really possible to analyse job satisfaction of self-employed across all sectors, because not all sectors have self-employed workers. More than a half of self-employed workers in agriculture, hunting and forestry were not satisfied with their current job (53.3\%). Among employees, women indicated a slightly higher job satisfaction $(76.3 \%)$ than men $(73.4 \%)$. Among self-employed workers, the opposite was observed: men - 59.5\%, women $-52.5 \%$. The highest rates of satisfied workers oc- 


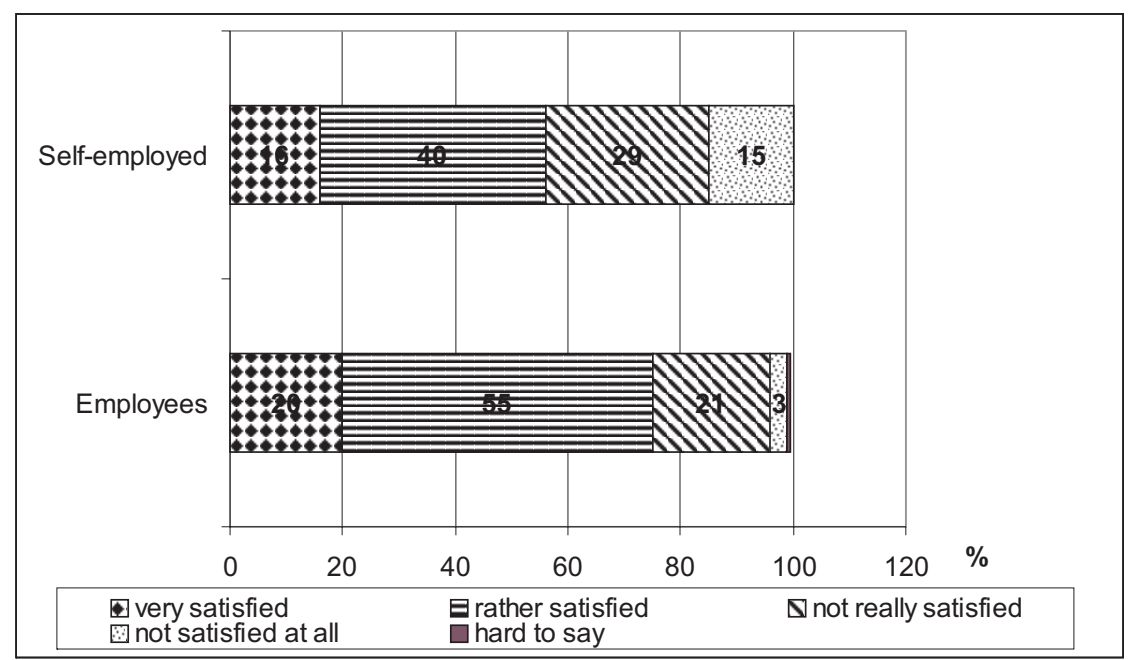

Fig. 1. Job satisfaction (\%) among employees ( $\mathrm{n}=$ $2455)$ and self-employed persons $(n=65)$ in Latvia (2006).

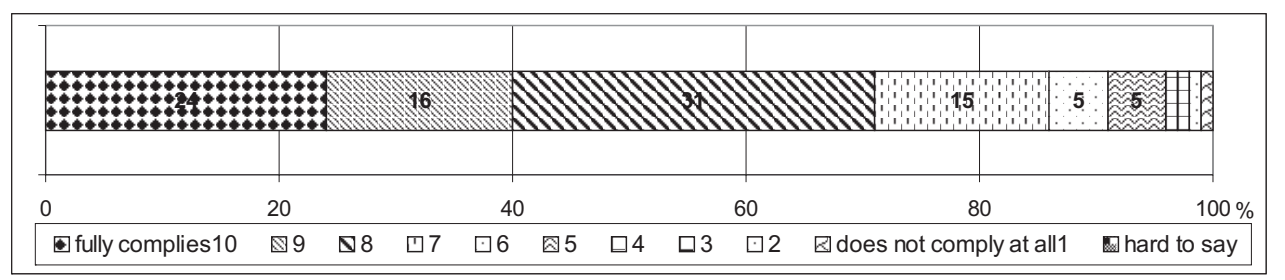

Fig. 2. Employers'( $\mathrm{n}=1058)$ self-assessment in a 10 point scale (10 is "full compliance"; 1 - "no compliance at all") of the compliance of working environment with the requirements of the Labour Protection Law in Latvia (2006).

curred among younger workers. There were significant differences $(P<0.05)$ in job satisfaction among respondents with different ethnical backgrounds. Ethnic Latvians had a substantially higher job satisfaction (79.2\%) than Russians $(68.3 \%)$ or other ethnic groups $(70.2 \%)$.

Enforcement of legislation. During the survey, employers were asked to self-assess the degree of compliance of their company with the requirements of the Labour Protection Law using a 10-point scale (10 is "full compliance" and 1 - "no compliance at all") (Fig. 2).

The perceived degree of compliance does not present a very optimistic picture for Latvia, because $86 \%$ of all respondents gave 7 to 10 points. A more in-depth assessment indicated that the real situation concerning the work environment in Latvia was much worse; $49.7 \%$ of the employers who thought that the work environment in their companies complied with the requirements of the Labour Protection Law (corresponding to 9 or 10 points in our scale), also indicated that occupational risk assessment in their enterprise has not been carried out. This indicates low awareness about the requirements of the Labour Protection Law. $44.0 \%$ of employers who considered that the work environment in their companies complied with the requirements of the Labour Protection Law also indicated that compulsory health examinations had not been carried out, but these are required in Section 15 of the Law.

The average national score of compliance with requirements of Labour Protection Law obtained through the survey of employers per sector is 7.9 in Latvia. There were significant differences among various sectors, with the highest self-assessment among employers in health and social work (8.8) and the lowest in manufacture of basic metals, fabri- cated metal products, machinery and equipment (7.3) (Table $1)$.

Occupational risk assessment. Although the requirement for occupational risk assessment in Latvia has been in force since 1 January 2002, more than half (54\%) of employers indicated that occupational risk assessment has never been carried out in their company or institution, or that it has been carried out only partly $(22 \%)$; only $22 \%$ indicated that occupational risk assessment has been carried out completely (Fig. 3).

Table 1

EMPLOYERS' SELF-ASSESSMENT OF COMPLIANCE OF THEIR COMPANIES WITH REQUIREMENTS OF THE LABOUR PROTECTION LAW, PER SECTOR IN LATVIA*

\begin{tabular}{lcc}
\hline \multicolumn{1}{c}{ Sector } & Average score \\
\hline Health and social work & 8.8 \\
Fishing & 8.4 \\
Other sectors (a number of sectors which are considered & 8.3 \\
to be low risk sectors) & \\
Manufacturing & 8.0 \\
Manufacture of food and beverages & 7.9 \\
Electricity, gas and water supply & 7.9 \\
Education & 7.9 \\
Construction & 7.8 \\
Agriculture, hunting and forestry & 7.8 \\
Mining and quarrying & 7.4 \\
Manufacture of wood, products of wood and cork manu- & 7.4 \\
facture furniture & \\
Manufacture of basic metals, fabricated metal products & 7.3
\end{tabular}

machinery and equipment

* Respondents who gave a certain quantified value $(\mathrm{n}=104)$. 


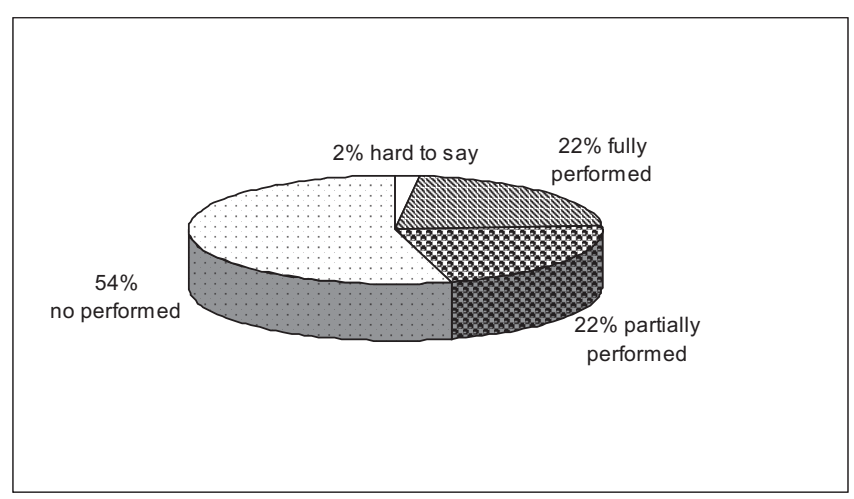

Fig. 3. Opinion of employers $(\mathrm{n}=1058)$ about occupational risk assessment in companies and enterprises in Latvia (2006).

According to the results of the survey of employers, most often legislation requirements regarding occupational risk assessment are not followed in: small (micro) companies; companies located in villages and rural areas; agriculture, the hunting and forestry sector companies, manufacturing sector; the private and nongovernmental sector; companies with a majority of local ownership; companies focusing on local markets; and new companies or reorganised ones.

Organisation of occupational health and the safety management system. During the survey, $8.1 \%$ of employers indicated that they did not have an occupational health and safety specialist. A total of $63.4 \%$ employers indicated that occupational health and safety tasks in their enterprise were carried out by him/her. At the same time, $61.6 \%$ of these employers had neither undergone occupational health nor safety training (160 hours) nor had higher professional education in this area. Most often occupational health and safety tasks were carried out by the employer him/herself in small companies (1-9 employees - 76.1\%, 10-49 employees - 31.6\%, 50-249 employees - 13.0\%, 250 and more employees $-5.5 \%$ ). In $22.6 \%$ of cases occupational health and safety measures were carried out by one occupational health and safety specialist, in $1.9 \%$ of cases — by several specialists or by a special unit. In $79.0 \%$ of cases occupational health specialists performed these duties along other, unrelated duties, and in $25.8 \%$ of cases, these specialists worked full time. A relatively small portion of employers had opted to use external services of competent specialists $(3.8 \%)$ or competent institutions $(2.0 \%)$.

Occupational risk factors. Occupational risk factors appear in all economic sectors and can affect a large number of employees. The ten most frequently mentioned risk factors according to employers' and employees' survey are listed below (Table 2).

The obtained information showed that at present psychosocial factors (shortage of time, overtime work, long working hours etc.) and ergonomic factors (work with a computer, lifting heavy objects, awkward posture, repetitive movements etc.) were the most essential occupation risk factors. This means that conventional risk factors have been substituted by modern ones. The analysis showed that microclimate and weather conditions should be considered as significant occupational problems.

\section{Analysis of database of measurements}

Analysis of the measured risk factors database of the Hygiene and Occupational Diseases Laboratory of the Institute of Occupational and Environmental Health of the Rìga Stradiņš University helped to assess compliance of the measured values with mandatory or recommended standards. More than one-third of measured values of most occupational risks exceeded mandatory or recommended limits (Fig. 4).

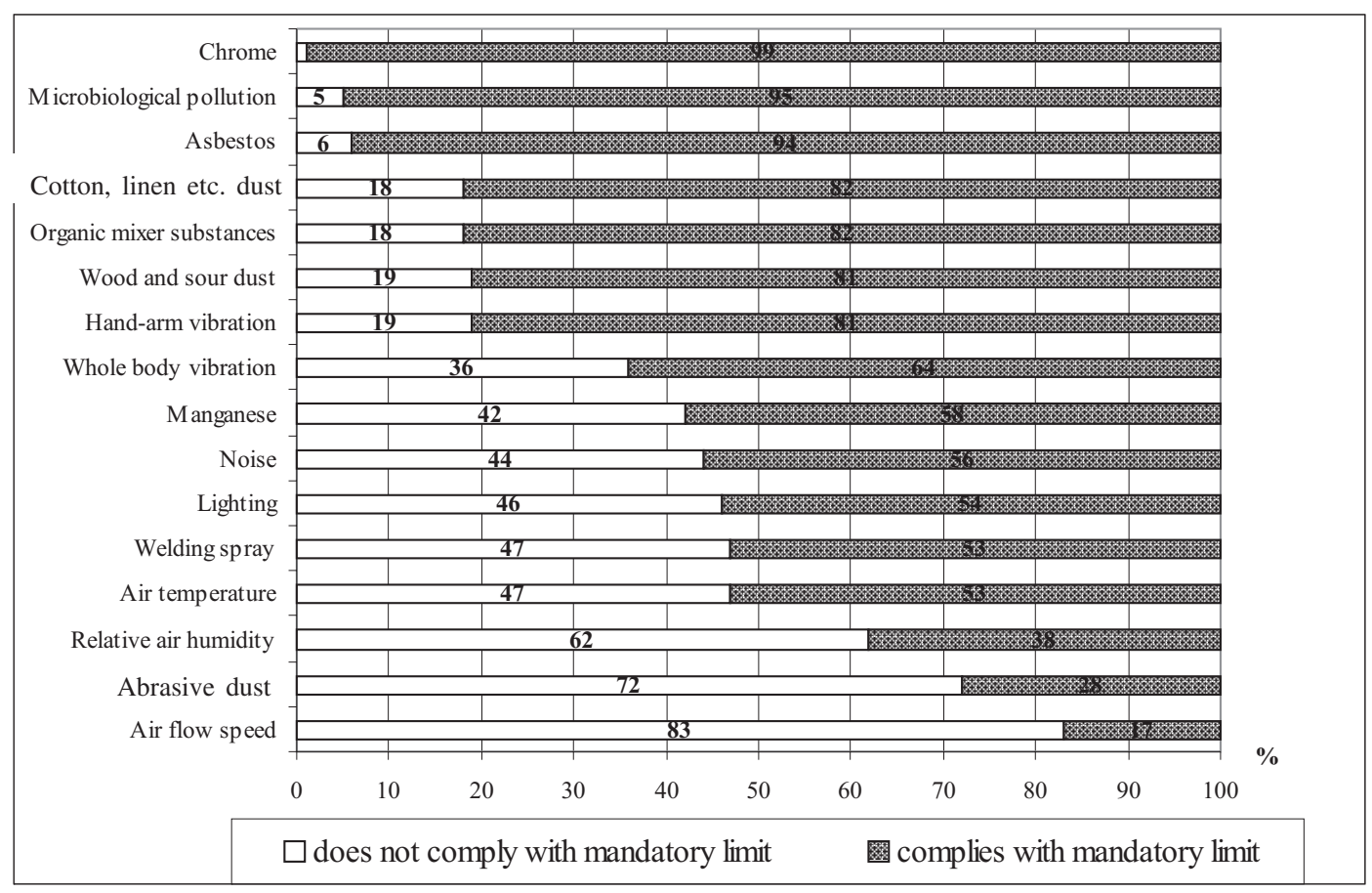

Fig. 4. Compliance (\%) of occupational risk factors with mandatory or recommended standards in Latvia in the period 1995-2006, according to the analysis of measurements $(n=13956)$ of the Laboratory of Hygiene and Occupational Diseases. 
More than one-third of analysis of physical factors - vibration $(36 \%)$, noise $(44 \%)$, and lightening (46\%) did not confirm corresponding mandatory or recommended values (see Fig. 4).

\section{Workplace accidents}

Workplace accidents were investigated and registered in compliance with a Regulation of Cabinet of Ministers. Data on workplace accidents provided by the State Labour Inspectorate were recalculated per 100000 employees (Fig. 5). Workplace accidents (1999 to 2005) per 100000 employees tended to decrease, in spite of an increase of workplace accidents in 2005. The number of fatal accidents per 100000 employees was relatively stable (with a slight decrease in 2003) with a decreasing trend (Fig. 5). Evaluation of data in sectors per 100000 employees showed a dramatic decrease in fatal accidents in wood processing (by 3.3 times) and logging (by 10.8 times) during 2002-2005, while there was an increase in sectors such as construction (by 1.1 times), transportation (by 1.2 times) and health care (by three times).

\section{Occupational diseases}

In Latvia occupational diseases are diagnosed and coded according to the International Classification of Diseases (Anonymous, 2007). For adequate comparison of occupational morbidity in Latvia with that of other States, absolute numbers of new cases of occupational diseases were recalculated per 100000 employees (Fig. 6). The number of occupational diseases and patients revealed for the first time during a year, gradually increased from 1996 until 2006 (five times). In 2005, there was a slight decrease in occupational diseases and patients registered for the first time.

Work-related health disorders. Occupation related disorders affect working ability of an individual and consequently also production process within the enterprise.

$33.2 \%$ of respondents acknowledged that they had or had had long-term health disorders, which negatively affected their everyday activities. Most often respondents mentioned chronic musculoskeletal health disorders (upper and lower back pain, aching joints) $-17.9 \%$, cardiovascular and pulmonary disorders $-8.8 \%$, and neurological disorders (including headache, bad memory, memory loss, vertigo, arm
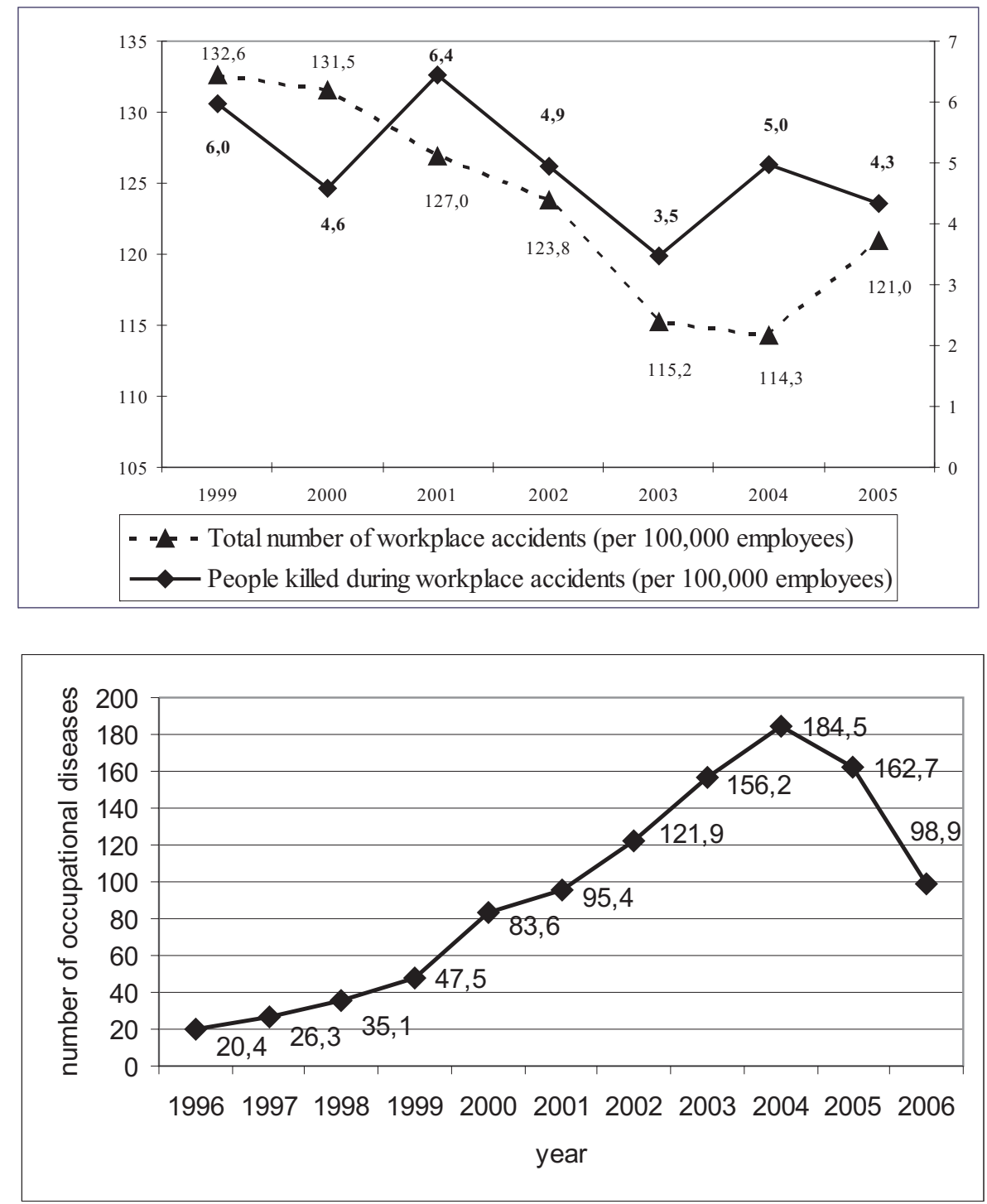

Fig. 5. Number of employees affected by workplace accidents per year in Latvia (per 100000 employees) in the period 1999-2005 
numbness) $-8.3 \%$. A total of $58.8 \%$ of respondents believed that these disorders were related to the work environment or work conditions, while an additional $6.7 \%$ pointed out that disorders started after an injury at work. Respondents having musculoskeletal disorders related their problems to work even more often, i.e., work environment and conditions - $63.9 \%$, workplace injuries - 9.8\%. People having cardiovascular and pulmonary diseases blamed working hazards $50.0 \%$, but people with neurological disorders $-46.3 \%$.

\section{Occupational health and safety - awareness, education and training}

Awareness levels among employers and employees. One of the study objectives was to determine awareness levels among employers concerning presence of occupational risks in any work environment, because practically there were no risk-free workplaces in Latvia. The employers' view of the number employees exposed to any occupational risks (chemical, physical, ergonomic, psychosocial, risks of injuries, others) is shown in Figure 7.

There was low understanding among employers about the possible impacts of occupational risks on their employees' health. Almost half of all respondents (42\%) indicated that none of their employees were subjected to occupational risk, $17 \%$ employers - that less than $40 \%$ workers subjected to occupational risk, and only $16 \%$ employers answered that $100 \%$ of their employees were exposed to occupational risk.

More than a half of the employees perceived that they were informed about occupational risks and their potential health impacts at their company, but in most cases the information that they received was not sufficient, or of good quality. $61.2 \%$ of employers ensured that their employees were aware of occupational risks at their workplaces (chemical, physical, ergonomic, psychosocial, trauma risks, others). $17.8 \%$ of the respondents (employees) thought that these issues were not of their concern, which indicates their low awareness and understanding of occupational risks and their impacts on health and safety. $18.6 \%$ of the respondents indicated that they did not need information. The highest rates of respondents indicating that they had not received information on occupational risks were among those employed in construction $(25.5 \%)$, manufacturing $(23.0 \%)$, agriculture, hunting and forestry, (22.3\%), and manufacture of wood and wood products and furniture $(21.6 \%)$. Men perceived that they were slightly better informed than women about occupational risks $(62.8 \%$ versus $51.6 \%)$ and about their health impacts $(63.2 \%$ versus $58.5 \%)$. Young workers considered that they were less informed compared with respondents of other age groups (18-24 years $-51.4 \%$, other age groups - between $55.1 \%$ and $58.7 \%$; health impacts: 18-24 years - 53.1\%, other age groups - between $58.5 \%$ and $65.5 \%$ ). No significant differences were found among respondents with different ethnic backgrounds (ethnic Latvians - 60.2\%, Russians - 60.8\%, and other ethnic groups $-62.5 \%)$.

Education and training of occupational health and safety specialists, quality of training. The procedure for education and training of occupational health and safety specialists is stated in the Regulation No. 323 (2003) of the Cabinet of Ministers of Latvia, "On occupational health and safety education and training". Occupational health and safety expertise can be obtained at the two following levels: 1) basic level, by undergoing a training programme licensed by the Ministry of Education and Science (a total of 160 hours of which 50 hours are theory); and 2) higher professional education, by undergoing an accredited education programme that complies with the professional standard "Occupational health and safety specialist" or "Senior occupational health and safety specialist".

A total of $46.9 \%$ of the employers could not evaluate the quality of basic training, because they had not used it. The survey results suggested that only $16.6 \%$ of the employers found their training very satisfactory, $73.0 \%$ - rather satisfactory, $9.0 \%$ - rather dissatisfactory, and $1.4 \%$ - very dissatisfactory.

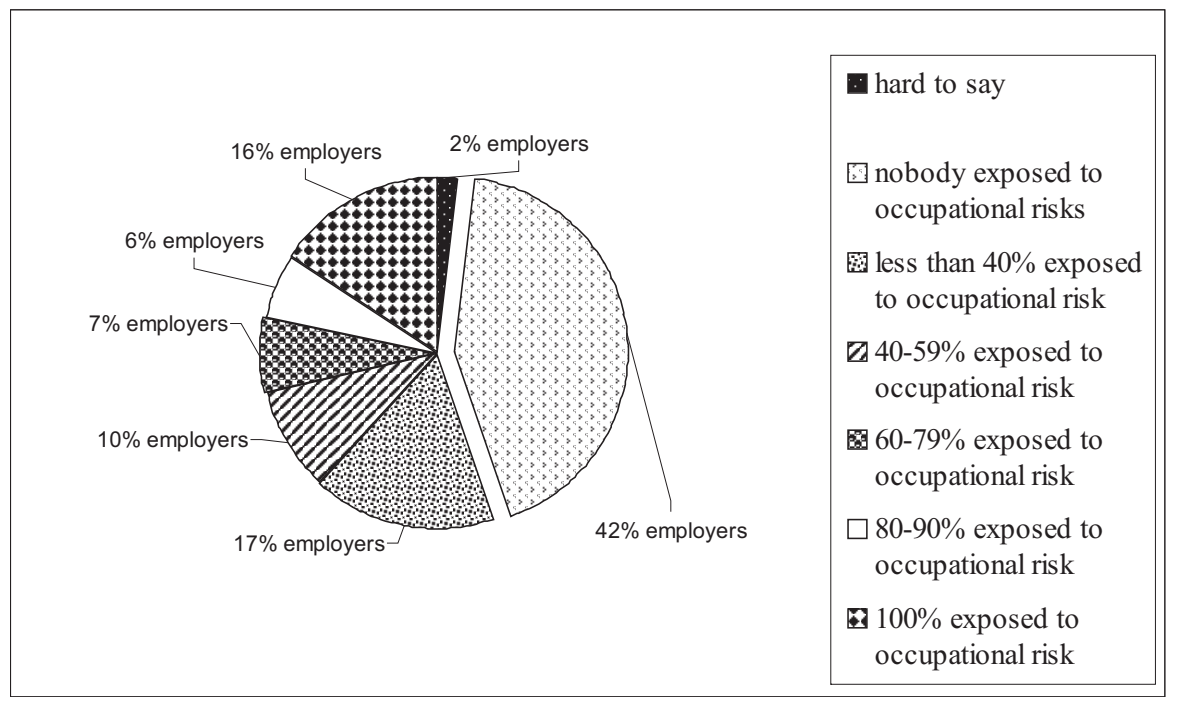

Fig. 7. Employers' $(\mathrm{n}=1058)$ view $(\%)$ of exposed employees in Latvian companies to any occupational risks 
$45.3 \%$ of occupational health and safety specialists indicated that they also had received basic training. In general, occupational health and safety specialists are satisfied with the quality of training, but $61.5 \%$ of the respondents considered that the actual content did not comply with standards. $51.3 \%$ specialists who had received basic level training in occupational health and safety thought that they were ready for practice work in companies, $48.7 \%$ considered the opposite.

Occupational health and safety specialists with higher education considered that it is necessary to periodically test knowledge (26\%) or refresh education (42\%). $12.8 \%$ of respondents thought that neither of the two was necessary. The same number of respondents indicated that refresher courses should be conducted once in three, or once in five years $(41.9 \%)$.

\section{DISCUSSION}

Analysis of the survey on job satisfaction and satisfaction with work conditions demonstrates that employees in Latvia (men and women) have generally higher job satisfaction (75\%) than self-employed persons (56\%). Among employees the most often mentioned reasons why people are satisfied with their current jobs were: "job security and stability, stable salary", "interesting, creative, dynamic and diverse job", "social guarantees", "good salary", "pleasant social contacts with colleagues".

The analysis of factors contributing to low job satisfaction showed differences between employees and self-employed persons. Among the self-employed, the most often mentioned reason was "lack of stability and sense of security", but employees most frequently mentioned "low salary" (76.2\%), "high workload", "bad and insecure working conditions, problems with working environment", "lack of stability and sense of security, salary is not paid on time".

Approximately the same number of employees were satisfied with their work conditions and work environment specifically from a perspective of occupational health and safety $(77.2 \%)$ as those who were satisfied with their current jobs.

Among the main reasons for employees not being satisfied with their working conditions and environment were: "many health risks (occupational risk factors)", "physically heavy work", "working environment does not suit the needs of workers", "dirty working environment", "the employer does not take care about working environment and occupational safety and health".

$18.9 \%$ of all respondents indicated that occupational health and safety conditions at their work place improved during 2006.

The survey of employers on enforcement of legislation indicates low awareness about the requirements of the Labour Protection Law: half of employers, who think that working environment in their companies comply with the requirements of the Labour Protection Law, also indicated that occupational risk assessment in their enterprise had not been carried out, they have also indicated that compulsory health examinations have not been carried out, but these are required in Section 15 of the Law.

Although the requirement for occupational risk assessment in Latvia has been in force since 1 January 2002, more than a half $(54 \%)$ of employers indicated that occupational risk assessment had never been carried out in their company or institution, or that it had been carried out only partly; only $22 \%$ indicated that occupational risk assessment had been carried out completely.

According to the results of the survey of employers and employees, occupational risk assessment requirements are more often not followed by the following types of companies: fishing, manufacturing, health and social work, and construction sectors; the private and non-governmental sectors; small (micro) companies; and companies that sometimes or always pay illegal "envelope salaries".

The survey revealed that the occupational health and safety management system is not properly organised in most than half of companies, part of employers $(8.1 \%)$ indicated that they did not have a occupational health and safety specialist, and more than $60 \%$ of employers had neither undergone occupational health and safety training (160 hours) nor had higher professional education in this area. Most often occupational health and safety tasks are carried out by the employer him/herself and a relatively small portion of employers had opted to use external services of competent specialists $(3.8 \%)$ or competent institutions (2.0\%).

Occupational risk factors appear in all economic sectors and can affect a large number of employees. The obtained information showed that at present psychosocial factors (shortage of time, overtime work, long working hours etc.) and ergonomic factors (work with a computer, lifting heavy objects, awkward posture, repetitive movements etc.) were the most essential occupation risk factors according to employers' and employees' survey. This means that conventional risk factors have been substituted by modern ones. The analysis showed that microclimate and weather conditions should be considered as significant occupational problems.

Analysis of measured risk factors database of the Laboratory of Hygiene and Occupational Diseases of the Institute of Occupational and Environmental Health of the Rìga Stradiņš University showed that more than one-third of measured values of most occupational risks in workplaces exceeded mandatory or recommended limits. Possibly, the measurements were carried out only in workplaces selected by the client, i.e. the most "dangerous" and "hazardous" workplaces. Improper microclimate (inappropriate air temperature, too low or too high relative air humidity, as well as too low or too high air movement) was the most important issue. Bad microclimate itself causes neither occupational diseases, nor workplace accidents. However, it nega- 
tively affects subjective condition and work ability of employees, thus decreasing the quantity and quality of the performed job, and could aggravate already prevalent diseases. For example, draught can worsen the course of musculoskeletal disorders. Inappropriate microclimate is mostly found in offices with bad air exchange and insufficient ventilation, in outdoor sheltered and semi-sheltered workplaces, as well as in workshops having draught (Eglite, 2000). Another essential occupational risk according to the database is dust, especially abrasive dust caused by abrasive tools (e.g., polishing equipment) and welding fumes. More than onethird of the analysis of physical factors (vibration, noise and lightening) does not confirm to the corresponding mandatory or recommended values.

Analysis of information on workplace accidents (1999 to 2005) per 100000 employees found a general trend towards decrease. The results of this study showed that there were relatively few workplace accidents compared to other European Union Member States. However, this is rather an indication of poor registration of workplace accidents than of a well-arranged and safe working environment. Analysis of occupational health and safety country profiles in EU prepared from Finish Institute of Occupational Health showed that incidences of fatal accidents ranged between 1 and 44 per 100000 employees. Authors noted that comparability across countries is slightly hampered by national differences in definitions, coverage and reporting (Rantanen et al., 2001).

Extended and complicated documentation of workplace accidents and coordination with the State Labour Inspectorate are reasons why employers do not want to report and register workplace accidents.

In Latvia occupational diseases are diagnosed and coded according to the International Classification of Diseases (Anonymous, 2007) and the situation is comparable with other States. The number of occupational diseases and patients occurring for the first time in a patient gradually increased from 1996 until 2006 (five times). Decrease in the number of first-time occupational diseases in 2005 could be explained by amendments in legislation regarding involvement of family doctors in compulsory medical examinations instead of occupational physicians. Incompetence of family physicians in occupation health problems connected with different risk factors could be one of the reasons leading towards decrease of occupational diseases diagnosed for the first time in 2005 compared to 2004 (Eglite et al., 2009).

In Latvia, 184.5 new cases per 100000 employees were registered in 2004 and 162.7 cases in 2005, while in 2000 the occupational morbidity rate was 83.6 cases per 100000 employees. In comparison to other countries, with a different system of registration of occupational diseases: in Russia (2000) there were diagnosed 18.1 new cases per 100000 employees; in Finland (2002) - 144.1 in Sweden (2003) 405.2 cases per 100000 employees (Rantanen et al., 2002; Antila et al., 2003; Eglite et al., 2009). It should be noted that during the last years occupation morbidity tended to de- crease in developed EU countries, while it was still increasing in Latvia. Work conditions in European Union in general are improving and correspondingly have led to decreased occupational morbidity rates. However, in Latvia improved diagnosis of occupational diseases still outpaced improvement of working conditions. Employees have become more aware of occupational risks and signs of occupational diseases; more and more employees are informed on possibilities of receiving financial support in case of occupational diseases (for example, knowledge on occupational risk factors has increased among health care professionals by $7.1 \%$, compared to 2002 (Vanadziņš et al., 2003).

The number of certified occupational physicians has increased from 50 in 1996 to 314 physicians in 2000 and 421 in 2006, and most probably the knowledge of physicians has improved as well (for example, duration of training courses for occupational physicians have increased from 50 hours in 1998 to 300 hours in 2006) (Eglite et al., 2009).

Similar to the situation worldwide, the structure of occupational diseases in Latvia changed during 1993-2005. Since 1999 , there was a dramatic increase in morbidity of diseases caused by physical overloads, such as musculoskeletal and connective tissue disorders, as well as carpal tunnel syndrome, but occurrence of occupational diseases caused by chemical substances and dust decreased.

Occupational hazards cannot only cause specific diseases, but also exacerbate chronic health disorders. The latter are not listed in Latvian legislation. Therefore, employees cannot receive compensation for this disorder.

The study revealed that ergonomic risk factors, which cause musculoskeletal problems, prevailed in the working environment. Employers have to pay more attention to such ergonomic occupational risks as lifting of heavy objects, awkward posture, fast repetitive movements, but the policy should focus on informing employers on different ergonomic risk assessment methods and preventive measures, as well as popularise activities that promote healthy and active way of living among employees.

One of the study purposes was to determine awareness levels among employers concerning presence of occupational risks in any work environment, because practically there were no risk-free workplaces in Latvia. There was a low understanding among employers about the possible impacts of occupational risks on health of their employees according to data of survey. More than a half of the employees perceived that they were informed about occupational risks and their potential health impacts at their company, but in most cases the information that they received was not sufficient and of good quality.

Continuing education of occupational health and safety specialists currently is not being organised and planned, and it is basically left upon the specialists themselves, by means of attending seminars in Latvia, literature search on the Internet, and consultations with experts in relevant sectors. 
Occupational health and safety specialists themselves (those with higher education or those undergoing such studies) consider that continuing education should be organised by higher education institutions; education and training centres, the State Labour Inspectorate, and non-governmental organisations specialising in occupational health and safety.

The conclusions are:

1) Results of the study indicated that the following enterprises form a risk group of non-compliance with legislation regarding occupational health and safety, as well as legal labour relations: small enterprises; enterprises of private and non-governmental sectors; enterprises of different industries (construction, metal processing, wood processing); and enterprises where illegal "envelope salaries" are paid.

2) Results of measurements showed that one-third of measured risk factors values exceeded mandatory or recommended limits, but the situation has been improved during the recent years (2002 compare to 2006). Survey results reveal insufficient assessment of risk factors in workplaces and selection of most hazardous ones only. However, occupational risk assessment is frequently carried out formally and disregarding legal requirements.

3) The traditional work risk factors (physical, chemical, biological) have changed to new ones risks (psychosocial shortage of time, overtime work, long working hours; ergonomic - work with a computer, handling of heavy objects, awkward posture, and repetitive movements, microclimatic) in Latvia today.

4) The risk group of awareness on occupational health and safety problems included managers of small and new companies, as they need information on the Labour Protection Law and regulations on occupational risk assessment. Among employees, respondents having less education and young workers form a risk group. Informative publications on occupational health and safety and legal labour relations should be short, clear, simple, laconic and easy to understand.

5) Data indicated relatively few workplace accidents in Latvia compared to other EU countries, which indicates poor registration system of workplace accidents in Latvia, and not a well-arranged and safe work environment.

6) The number of occupational diseases in first-time patients gradually increased from 1996 to 2006. The increase of registered occupational diseases is also related to growing awareness of employees, increasing number of occupational physicians, as well as the possibility to receive monetary compensation.

7) Early diagnosis of occupational diseases during compulsory medical examinations is essential. This will reduce the necessity for compensations from the Special Budget for workplace accidents to be paid in cases of permanent loss of work ability. To facilitate return of employees to the labour market after occupational illnesses, the focus should be switched to effective rehabilitation.

8) An insufficient number of employers, employees and self-employed are informed on legal requirements, as well as on their responsibilities and rights. The study indicated a need to improve occupational health and safety legislation, as well as to create system for explaining the respective legal requirements and building public awareness; and to elaborate several occupational health and safety papers.

\section{ACKNOWLEDGMENTS}

The research was conducted within the Project "Studies of the Ministry of Welfare" No. VPD1/ESF/NVA/04/NP/ 3.1.5.1.10003 of the National Programme" Labour Market Studies" and Financed by European Structural Fund.

The authors are thankful to TNS Latvia Ltd. and Market Lab Ltd. for their practical help.

\section{REFERENCES}

Anonymous (1995). Global Strategy on Occupational Health for All. World Health Organisation. 14 pp.

Anonymous (2007). International Statistical Classification of Diseases and Related Health Problems. 10th Revision. World Health Organisation. http://www.who.int/classifications/ icd/en/.

Anonymous (2003). European Foundation for the Improvement of Living and Working Conditions.

http://www.eurofound.eu.int/publications/files/EF0306LV.pdf .

Antila, J., Ilestalo, P. (2003). Darba dzīves barometrs Baltijas valstīs 2002. gadā [The Gender Pay Gap in Latvia 2002]. Somijas valsts Darba ministrija, 271 lpp. (in Latvian).

Eglīte, M. (2000). Darba medicīna [Occupational Medicine]. Rīga. 500 lpp. (in Latvian).

Eglite, M., Vanadzins, I., Matisane, L. (2002). Basic information on Latvia and its health system. In: Work and Health Country Profiles of Twenty Two European Countries. People and Work Research Reports. Vol. 52 (pp. 239-256). Rantanen, J., Kauppinen, T., Lehtinen, S., Mattila, M., Toikkanen, J., Kurpa, K., Leino, T. (eds.). Helsinki: Finnish Institute of Occupational Health.

Ijzelenberg,W., Molenaar, D., Burdorf, A. (2004). Different risk factors for musculoskeletal complaints and musculoskeletal sickness absence. Scand. J. Work Environ. Health, 30(1), 56-63.

Jankauskas, R. (2000). Occupational risk assessment: The case of Lithuania. In: Proceedings of European Centre for Occupational Health, Safety and Environment (ECOHSE) 2000 Symposium.

http://www.gla.ac.uk/ecohse/2000papers/Jankauskas-risk.pdf.

Kauppinen, T., Hanhela, R., Heikkilä, P., Kasvio, A., Lehtinen, S., Lindström, K., Toikkanen, J., Tossavainen, A. (2006). Work and Health in Finland. In: Changes in Work and Working Conditions in 1997-2006. http://www.ttl.fi/Internet/English/Information/ Electronic publications/ pdf.

Lassen, C.F., Mikkelsen, S., Kryger, A.I., Andersen, J.H. (2005). Risk factors for persistent elbow forearm and hand pain among computer workers. Scand. J. Work Environ. Health, 31(2), 122-131.

Rantanen, J., Kauppinen, T., Lehtinen, S., Mattila, M., Toikkanen, J., Kurpa, K., Leino, T. (2002). Work and Health Country Profiles of Twenty Two European Countries. Helsinki: Finnish Institute of Occupational Health. 444 pp.

Rantanen J., Kauppinen T., Toikkanen J., Kurpa K., Lehtinen S., Leino T. (2001). Work and health country profiles and national surveillance indica- 
tors in occupational health and safety. In: People and Work Research Reports. Vol. 44. Helsinki: Finnish Institute of Occupational Health.

Riedman, A., Bielenski, H., Szczurowska, T., Wagner, A. (2006). Working Time and Work Life Balance in European companies. Report by the European Foundation for the Improvement of Living and Working Conditions. Dublin. $70 \mathrm{p}$.

Roja, Z., Kalkis, V., Vain, A., Kalkis, H., Eglite, M. (2006). Assessment of skeletal muscle fatigue of road maintenance workers based on heart rate monitoring and myotonometry. J. Occup. Med. Toxicol., July 27, 1-20.

Vanadziňš, I., Eglīte, M., Roja, Ž., Mangule, R., Sečina, J., Borherte, L. (2003). Veselības un sociālās aprūpes darbinieku arodveselība Latvijā [Occupational health of medical and social health care workers in Latvia]. Latvijas Ārstu Žurnāls, 2, 26-30.

Received 13 April 2010
Viikari-Juntura, E., Häkkänen, M., Riihimäki, H., Martikainen, R., Takala, E-P., Rauas, S., Malmivaara, A., Jäppinen, P. (2001). Risk factors for incident low back disorders: A case-control and case-crossover study. Abstract Book of the 4th International Scientific Conference on Prevention of Work-Related Musculoskeletal Disorders. Amsterdam, p. 47.

Фарбтух Т.А., Эглите М.Э., Матисане Л.В. (2002). Профессиональная медицина в Латвии [Occupational medicine in Latvia]. Мед. тр. пром. экол., 12, 16-21 (in Russian).

Эглите, М.Э., Ванадзиньш И.А., Ресте Е.Д., Чурбакова Э.В., Баке М.Я., Спруджа Д.Р., Иванова И.А. (2009). Анализ условий труда и профессиональной заболеваемости в Латвии как основа для разработки стратегии по медицине труда. В кн.: Реализация Глобального плана действй по здоровью работающих в Российской Федерациию. Проблемы и перспективы. НИИ Медицины труда РАМН Москва: Сотрудничающий центр ВОЗ, 195-197 (in Russian).

\section{DARBA APSTĀKLII UN ARODA VESELĪBAS RISKA FAKTORI LATVIJĀ DESMIT GADU PERIODĀ}

Pētījuma mērkis bija radīt analītisko bāzi aroda veselības, darba drošības un darba tiesisko attiecību jomā, kas kalpotu par pamatu racionālu un efektīvu lēmumu pieṇemšanai nodarbinātības un sociālo programmu radī̌anai un darba drošības un aroda veselības attīstības programmu nodrošināšanai. Pētījuma laikā veiktas un analizētas darba devēju, nodarbināto un darba aizsardzības speciālistu aptaujas, analizēti darba vides riska faktoru laboratorisko mērījumu datu bāzē apkopotie rezultāti, iegūta informācija par darba devēju, nodarbināto un darba aizsardzības speciālistu izglîtību, apmācību un informētību par riska faktoriem. Latvijā notikusi tradicionālo (fizikālo, kīmisko, bioloğisko) riska faktoru nomaiņa uz jauniem, mūsdienīgiem (psihoemocionāliem, ergonomiskiem, mikroklimata) riska faktoriem. Darba vides riska faktoru laboratorisko mērījumu analizētā datu bāze rāda, ka trešā daḷa mērīto riska faktoru rādītāju darba vietās Latvijā neatbilst noteiktiem vai rekomendētiem lielumiem, savukārt darba vides riska faktoru novērtējums un tā atbilstība normatīvo aktu prasībām ir uzlabojusies, salīdzinot 2002. un 2006. gadu. Tomēr aptauju dati parāda, ka riska faktoru novērtējums netiek veikts pietiekami bieži un notiek bīstamāko un kaitīgāko darba vietu atlase. Pētījuma rezultāti liecina par samērā nelielo reǵistrēto nelaimes gadījumu skaitu, salīdzinot ar citām Eiropas valstīm, kas varētu norādīt uz to zemo reǵistrācijas līmeni Latvijā. Aroda veselības norrnatīvās bāzes nostiprināšanās un arodslimību ārstu kvalifikācijas celšanās ir palielinājusi pirmreizēji atklāto arodslimnieku un arodslimību gadījumu skaita pakāpenisku pieaugumu laika posmā no 1996. līdz 2006. gadam. Īpaši svarīga ir arodslimību agrīna diagnosticěšana, lai veicinātu nodarbināto ātrāku atgriešanos darba tirgū pēc arodsaslimšanas, nopietna uzmanība ir jāpievērš arī viņu efektīvai rehabilitācijai. Pētījums parāda, ka darba drošības un aroda veselības jomā galvenā vērība ir jāpievērš normatīvo prasību vienkāršošanai, alternatīvo metožu attīstībai nodarbināto informēšanai un izglītošanai, kā arī atkārtotai indikatoru izvērtēšanai, lai novērtētu darba drošības un aroda veselības pasākumu efektivitāti. 